\title{
Yield and Nitrogen Content of Wheat (Triticum aestivum) as Affected by FYM and Urea in Cold Arid Region of India
}

\author{
Aamir Hassan ${ }^{1}$, Ajaz Malik ${ }^{1}$, Shahid Ahmad ${ }^{1}$, Malik Asif ${ }^{2 *}$, \\ S.A. Mir ${ }^{3}$, Owais Bashir ${ }^{3}$ and R. Safal ${ }^{1}$ \\ ${ }^{1}$ Krishi Vigyan Kendra, Leh, Ladakh, India \\ ${ }^{2}$ Division of Basic Sciences and Humanities, FOA, Wadura, India \\ ${ }^{3}$ Division of Soil sciences and Agricultural chemistry, FOA, Wadura, India \\ Sher-e-Kashmir University of Agricultural Sciences and Technology-Kashmir \\ *Corresponding author
}

A B S T R A C T

\begin{tabular}{|c|}
\hline Keywords \\
\hline $\begin{array}{l}\text { Farm Yard Manure, } \\
\text { Urea, Nitrogen } \\
\text { Uptake, Wheat, } \\
\text { Yield }\end{array}$ \\
\hline Article Info \\
\hline $\begin{array}{l}\text { Accepted: } \\
\text { 04 January } 2018 \\
\text { Available Online: } \\
\text { 10 February } 2018\end{array}$ \\
\hline
\end{tabular}

In the current study an experiment was carried out through the integrated use of organic manure (FYM) and inorganic fertilizers (Urea) on sandy loam soils of the cold arid region of India during 2015-2016. The incorporation of both organic manures and inorganic fertilizers met the total need of nitrogen in wheat i.e., $120 \mathrm{~kg} / \mathrm{ha}$. The nutrient supply from both the sources was arranged in various combinations 0:0, 100:0, 25:75, 50:50, 75:25 and $0: 100$. Wheat variety HS-375 was taken in the experiment. The data on yield attributing characters yield and soil nutrient status were recorded. Nitrogen content of wheat grain was also analysed. The result was maximum in the combination having urea and FYM in the ration of 75:25, followed by treatment procuring nitrogen frm two sources in the ratio of 50:50. In grain, nitrogen content was highest in treatment receiving nitrogen $100 \%$ from urea followed by applying 100\% FYM. After the crop harvest, the residual soil organic fertility was proportional to ratio of FYM used. The data in the study represented a conclusion that integrated farming using FYM and urea in the combination of 75:25 and 50:50 produced maximum yield.

\section{Introduction}

Wheat in one of the most important crop of India and it has been grown in every state. Wheat is an exhaustive crop and requires large amount of nutrients, so the use of chemical can't be completely avoided. The most fascinating thing about chemical fertilizers is that it is readily available and crop response is very high, but its continuous use meteorite soil health. On the agriculture sector there has been an immersed pressure to produce more food and fodder. In the cold arid region as the environmental conditions are not so favourable there has been a tremendous pressure on soil health (Sharma et al., 2006). Soils in the cold arid region have different types and perform differently as they have coarse texture, low nutrient availability, low nutrient and water holding capacity. The crop growth and yield is extremely uneven. Boosting the crop production without 
fertilizers is not possible and in the present day scenario growing of a wheat crop without these fertilizers is rater a miracle. In the cold arid region (Ladakh) of India, the cost of chemical fertilizers is higher and easily not available and these alone cannot meet the needs of productivity. Organic source with inorganic sources are more suitable. This integration not only reduced the cost of cultivation but also is an environment friendly approach. Incorporation of organic manures alone or in combination with inorganic fertilizers maintained soil fertility and proper nutrition to crop. The efficiency of chemical fertilizers was measured by their application with organic manures (Hussain et al., 1988)

In this way an experiment was conducted to evaluate the integrated use of urea and FYM on nitrogen content and yield of wheat in cold arid region (Leh, Ladakh) of India.

\section{Materials and Methods}

A field experiment was conducted at Research Farm of Krishi Vigyan Kendra, Leh, Ladakh, SKUAST-K during 2015 and 2016 to evaluate the effect of integrated use of urea and FYM on nitrogen content and crop yield of wheat. FYM and urea were applied to supply $120 \mathrm{~kg} / \mathrm{ha}$ of nitrogen in different ratios i.e., 0:0 $\left(\mathrm{T}_{0}\right)$, 100:0 $\left(\mathrm{T}_{1}\right)$, 25:75 $\left(\mathrm{T}_{2}\right)$, 50:50 $\left(\mathrm{T}_{3}\right)$, 75:25 $\left(\mathrm{T}_{4}\right)$, and 0:100 $\left(\mathrm{T}_{5}\right)$. The treatments were organised in randomized complete block design with four replications. Well rotten FYM was obtained from kvk-leh Dairy unit and analysed for total nitrogen.

The field was thoroughly prepared. According to the experimental plan, a layout was carried out with plot size of $4 \times 4 \mathrm{~m}^{2}$. In relevant treatment plots FYM and urea were uniformly distributed in appropriate ratio and were thoroughly mixed with the soil. In the treatments where nitrogen demand was below $60 \mathrm{~kg} / \mathrm{ha}$ from urea, all the urea was applied at sowing, while in other treatments which required nitrogen above $60 \mathrm{~kg} / \mathrm{ha}$ from urea, then the urea was applied in split dosed. One half at sowing and other half at second irrigation. The phosphorus @ 90kg/ha and potassium @60kg/ha were also applied as basal dose. Wheat was sown in rows with proper distance after seed bed preparation and fertilizer application and interculture operations were done properly.

\section{Soil and plant analysis}

The organic carbon was determined by rapid titration method given by Walkley and Black (1934). Kjeldhal method of Bremner and Mulvaney (1982), was used for determination of total nitrogen in wheat grains. Subbiah and Asija (1956) alkaline permanganate method was used for determination of mineral nitrogen $\left(\mathrm{NH}_{4}-\mathrm{N}\right.$ and $\left.\mathrm{NO}_{3}-\mathrm{N}\right)$. Soil $\mathrm{pH}$ was determined by using digital $\mathrm{pH}$ meter having ratio of soil and water (1:2.5) given by Jackson (1973).

\section{Results and Discussion}

The results determined that all the fertilizers significantly $(\mathrm{P}<0.05)$ enhanced the yield attributing characters and the yield of wheat as compared to that of control treatment (Table 1). The plant height was also significantly $(\mathrm{P}<0.05)$ greater in fertilizer treatment than that of control. The maximum plant height of $84.75 \mathrm{~cm}$ was recorded in the treatment obtaining nitrogen from FYM and urea in the ratio of 75:25 followed by 50:50 and 100:00 ratio. The control treatment receiving no FYM and urea has minimum plant height of 73.6 $\mathrm{cm}$. significantly in integrated fertilized treatment, the maximum grain yield of wheat $34.70 \mathrm{q} / \mathrm{ha}$ was recorded in treatment obtaining nitrogen from FYM and urea in 75:25 ratio succeeded by $33.92 \mathrm{q} / \mathrm{ha}$ in treatment obtaining nitrogen from two sources in 50:50 ratio. A significant lowest grain yield 
was recorded in treatment receiving nitrogen solely from FYM than other fertilizes treatments. Rathore et al., (1995), Dudhat et al., (1996), Vyas et al., (1997) and Kumar and Singh (1997) recorded similar observations of obtaining higher yield of wheat grain with the combined application of FYM and inorganic fertilizers.

Similarly, the straw yield of wheat was significantly maximum in treatments obtaining nitrogen from FYM and urea in ratio 75:25 followed by the treatment ratios of 50:50and 100:0. The minimum straw yield was recorded in the control treatment followed by treatment receiving $100 \%$ nitrogen from FYM. The results in this experiment showed that the combination of the organic and inorganic sources resulted in higher yield of straw and the better straw yield in the treatment receiving more than $50 \%$ nitrogen from urea. The maximum straw yield was in the treatments receiving $100 \%$ nitrogen from urea.

Urea was considered as rapid and more influential source of nitrogen than FYM fir increasing growth of wheat but the combination of two sources in the ratio of 75:25 and 50:50 was found more effective. By the application of FYM and urea, there has not only increase in yield and yield attributing characters but also it enhanced soil physical condition and soil fertility for better wheat crop growth (Azad et al., 1998; Sushila and Giri, 2000).

\section{Nitrogen content in grain}

There has been a variable response of different fertilizers on nitrogen content in wheat as reported in table 1 . The maximum nitrogen concentration of $1.50 \%$ was obtained in treatment procuring $100 \%$ nitrogen from FYM, followed by treatment receiving $100 \%$ nitrogen from urea $(1.46 \%)$. These results are coinciding results of Vyas et al., (1997) who also recorded that incorporation of FYM notably enhanced nitrogen uptake in grains and straw of wheat. There has been a significant improvement in grain and straw yield also due to application of phosphorus and potassium.

Table.1 Plant height, grain and straw yield and nitrogen content of wheat as affected by integrated use of urea and farm yard manure

\begin{tabular}{|c|c|c|c|c|c|c|}
\hline & \multicolumn{2}{|c|}{ Treatment } & \multirow{2}{*}{$\begin{array}{l}\text { Plant } \\
\text { Height } \\
\text { (cm) }\end{array}$} & \multirow{2}{*}{$\begin{array}{l}\text { Grain } \\
\text { Yield }\end{array}$} & \multirow{2}{*}{$\begin{array}{l}\text { Straw } \\
\text { Yield }\end{array}$} & \multirow{2}{*}{$\begin{array}{l}\text { Nitrogen } \\
\text { content in } \\
\text { grain }(\%)\end{array}$} \\
\hline & $\% \mathrm{~N}$ from Urea & $\begin{array}{c}\% \text { N from } \\
\text { FYM }\end{array}$ & & & & \\
\hline$\overline{\mathrm{T}_{0}}$ & 0 & 0 & 73.6 & 29.62 & 54.65 & 1.29 \\
\hline$T_{1}$ & 100 & 0 & 78.73 & 32.12 & 61.06 & 1.46 \\
\hline$\overline{T_{2}}$ & 25 & 75 & 76.25 & 31.28 & 58.21 & 1.42 \\
\hline$T_{3}$ & 50 & 50 & 81.53 & 33.92 & 63.54 & 1.37 \\
\hline$T_{4}$ & 75 & 25 & 84.75 & 34.7 & 64.87 & 1.34 \\
\hline$\overline{T_{5}}$ & 0 & 100 & 74.98 & 30.82 & 56.86 & 1.5 \\
\hline & CD & & 14.8 & 7.27 & 8.64 & 3.81 \\
\hline
\end{tabular}


Table.2 Effect of integrated use of urea and farm yard manure on soil nutrient status in wheat

\begin{tabular}{|c|c|c|c|c|c|c|c|}
\hline & \multicolumn{2}{|c|}{ Treatment } & \multirow[t]{3}{*}{ pH $(1: 2.5)$} & \multirow{3}{*}{$\begin{array}{l}\text { OC } \\
(\%)\end{array}$} & \multirow[t]{2}{*}{$\mathbf{N}$} & \multirow[t]{2}{*}{$\mathbf{P}$} & \multirow[t]{2}{*}{$\mathbf{K}$} \\
\hline & \multirow{2}{*}{$\begin{array}{l}\% \\
\text { from } \\
\text { Urea }\end{array}$} & \multirow{2}{*}{$\begin{array}{l}\% \quad \mathrm{~N} \\
\text { from } \\
\text { FYM }\end{array}$} & & & & & \\
\hline & & & & & \multicolumn{3}{|c|}{ (kg/ha) } \\
\hline$T_{0}$ & 0 & 0 & 8.1 & 0.35 & 305.68 & 8.1 & 305.13 \\
\hline$T_{1}$ & 100 & 0 & 7.9 & 0.4 & 334.32 & 9.58 & 341.29 \\
\hline $\mathbf{T}_{2}$ & 25 & 75 & 8.2 & 0.56 & 403.23 & 17.65 & 391.1 \\
\hline $\mathbf{T}_{3}$ & 50 & 50 & 7.8 & 0.51 & 383.21 & 15.84 & 372.66 \\
\hline $\mathbf{T}_{4}$ & 75 & 25 & 8.5 & 0.48 & 369.84 & 11.21 & 350.02 \\
\hline$T_{5}$ & 0 & 100 & 8.6 & 0.68 & 442.54 & 19.24 & 402.36 \\
\hline & CD & & 0.33 & 0.12 & 43.3 & 5.8 & 38.4 \\
\hline
\end{tabular}

\section{Soil fertility at harvest stage}

After the harvest, the soil analysis shows higher nutrient status of organic carbon, available $\mathrm{N}, \mathrm{P}$ and $\mathrm{K}$ in the fertilized treatments than in control. the maximum mineral nutrients in soil (available $\mathrm{N}$ ) of $442.54 \mathrm{~kg} / \mathrm{hs}$ was obtained in treatment receiving $100 \%$ nitrogen from FYM followed by $403.25 \mathrm{~kg} / \mathrm{ha}$ in treatment receiving $75 \%$ nitrogen from FYM and 25\% from urea. The control was having the lowest available phosphorus and potassium followed by treatment receiving nitrogen $75 \%$ from FYM and $25 \%$ from urea was having available phosphorus and potassium in range of 17.65 and $391.10 \mathrm{~kg} / \mathrm{ha}$. The treatment receiving $100 \%$ nitrogen from FYM was having the highest available $\mathrm{P}$ and $\mathrm{K}$ in the range of 19.24 and $402.36 \mathrm{~kg} / \mathrm{ha}$ (Table 2).

The organic matter of soil was highest in that treatment which received $100 \%$ nitrogen from FYM followed by the treatment receiving nitrogen from $75 \%$ FYM and 25\% urea. These were at par with the organic matter content of control.

\section{References}

Azad, B.S., Gupta, S.C. and Peer, A.C. 1998. Influence of organic and inorganic fertilizers in maximizing wheat yield at irrigated conditions. Environment and Ecology 16(1): 71-73.

Bremner, J.M., Mulvaney, C.S. 1982. Methods of soil analysis, part 2 chemical and microbiological properties. Pp. 595-624.

Dudhat, M.S., Malavia, D.D., Mathukia, R.K. and Khanpara, V.D., 1996. Effect of organic manures and chemical fertilizers on wheat (Triticum aestivum L.) and their residual effect on green gram (Phaseolus radiatus L.). Gujarath Res. J., 22(1): 4-8.

Hussain, T. G. Jullani, and M. Z. Iqbal. 1988. Integrated use of organic and inorganic $\mathrm{N}$ fertilizer in rice-wheat cropping system. Pak. J. Soil Science. 3:19-23.

Jackson, M.L. 1973. Soil Chemical Analysis. Prentice Hall of India (Pvt.) Limited, New Delhi.

Kumar, R., and C. M. Singh. 1997. Crop yields and economics under fertilizer resource constraints along with different FYM application in maize-wheat cropping sequence. J. Hill Res.10 (2):103-107.

Rathore, R. L., S. J. Chipde, and A.R. Pal. 1995. Direct and residual effects of bioorganic and inorganic fertilizers in ricewheat cropping system. Ind. J. Agron. 40(1): 14-19. 
Sharma, V. K., Dwivedi, K. S., Tripathi. D., Ahmed, Z. 2006. Status of available major and micronutrients in the soils of different blocks of Leh district of cold arid region of Ladakh in relation to soil characteristics. Journal of the Indian Society of Soil Science. 54, 248-250.

Subbiah, B.V. and Aaija, G.L. 1956. A rapid procedure for the estimation of availability nitrogen in soils. Current Science 25, 259-260.

Sushila, R. and Giri, Gajendra. 2000. Influence of farmyard manure, nitrogen and biofertilizers on growth, yield attributes and yield of wheat (Triticum aestivum) under limited water supply. Indian Journal of Agronomy 45(3): 590-595.

Vyas, S. H., M. M. Modhwadia, and V. D. Khanpara. 1997. Integrated nutrient management in wheat. Gujarat Agric. Univ. Res. J. 23 (1):12-18.

Walkley, A. and Black, I.A. 1934. An examination of the Degtjareff method for determining soil organic matter, and proposed modification of the chromic acid titration method. Soil Science 37 , 29-38.

\section{How to cite this article:}

Aamir Hassan, Ajaz Malik, Shahid Ahmad, Malik Asif, S.A. Mir, Owais Bashir and Safal, R. 2018. Yield and Nitrogen Content of Wheat (Triticum aestivum) as Affected by FYM and Urea in Cold Arid Region of India. Int.J.Curr.Microbiol.App.Sci. 7(02): 328-332.

doi: https://doi.org/10.20546/ijcmas.2018.702.043 